\title{
Flight activity, reproduction, and adult nutrition of the beet webworm, Spoladea recurvalis (Lepidoptera: Pyralidae)
}

\author{
Yoichi SHIRAI* \\ National Institute for Agro-Environmental Sciences; Tsukuba 305-0856, Japan
}

(Received 9 August 2005; Accepted 20 March 2006)

\begin{abstract}
The adult longevity, reproductive period, age-specific flight activity, suitable temperature range for flight, and effect of adult feeding on the subsequent flight of Spoladea recurvalis Fabricius were studied in the laboratory. Flight activity was evaluated using a tethered flight-mill. Females had a pre-oviposition period of $3 \mathrm{~d}$, and continued to lay eggs up to $20 \mathrm{~d}$ post-emergence. Females flew longest between 17 and $23^{\circ} \mathrm{C}$, and $10 \%$ of females were capable of continuous long-duration flight even at $12^{\circ} \mathrm{C}$. Females flew more actively in their pre-oviposition period, but the females' reproduction period was not clearly separated from their active flight period. The mating status of females had no clear effect on their flight activity. Uptake of honey solution (nectar) was essential for adult survival, and the survival rate was reduced markedly when honey solution was withheld. When honey solution was supplied after $5 \mathrm{~d}$ of starvation, the overall longevity of the moths was the same as that of the moths continuously supplied with honey solution since emergence. When honey solution was removed even for $1 \mathrm{~d}$, subsequent flight activity was significantly depressed. Thus, the prediction that the strong propensity for long flights by $S$. recurvalis may be derived from their dispersal flights to seek flower nectar was not supported from the present experiment.
\end{abstract}

Key words: Adult nutrition; flight-mill; migration; reproduction; Spoladea recurvalis

\section{INTRODUCTION}

The majority of the studies on the relationship between flight and reproduction have been conducted for an insect species that displays wing polymorphism, such as planthoppers, stinkbugs, crickets, and aphids (Rankin and Burchsted, 1992; Fujisaki, 1994; Dingle, 1996; Zera and Denno, 1997; Langellotto et al., 2000). Among lepidopterans, noctuid moths have been relatively well studied from the viewpoint of flight and reproduction (Gatehouse, 1994; Showers, 1997; Saito, 2000). However, few studies have been done on the flight and reproduction behaviors of pyralid moths. They include important migratory species such as the rice leafroller, Cnaphalocrosis medinalis Guenée (Wada et al., 1988), or the bean podborer, Maruca vitrata Fabricius (previously M. testulalis) (Bottenberg et al., 1997). The flight behavior of this group needs to be studied more because there are an enormous number of Pyralidae (Zhang, 1994).
Spoladea recurvalis Fabricius is widely distributed from tropical and subtropical regions, feeding on Amaranthaceae, Chenopodiaceae, and Portulaceae plants (CAB Internatinal, 1991, 2000), and is thought to be a migratory species in Europe (Goater, 1986; Clancy, 1991). This species has been frequently caught on the Pacific Ocean or the East China Sea (Suzuki et al., 1977; Yoshimatsu, 1991), and by aerial net traps in the inland area of east central China (Riley et al., 1994, 1995). S. recurvalis cannot survive winter even in the southernmost part of Japan (Kyushu Island), because they have no hibernation stage and are less tolerant of cold temperatures (Yamada and Koshihara, 1976; Miyahara, 1991). In Japan, S. recurvalis is thought to be one of the lepidopterous insects that migrate overseas from subtropical and tropical regions, together with $C$. medinalis, during the rainy season (Yamada et al., 1979; Miyahara, 1997). The status of the reproductive maturity of females caught on the sea and flight behavior from a paddy

* E-mail: flight@niaes.affrc.go.jp

DOI: 10.1303/aez.2006.405 
field have been relatively well studied for the $C$. medinalis (Waldbauer et al., 1980; Wada et al., 1988; Miyahara, 1990; Miyahara and Sogawa, 1996), whereas none of these aspects have been evaluated for $S$. recurvalis.

In an earlier study, the author examined the flight and reproduction behaviors of three Pyraustine species, Hellula undalis Fabricius, Crocidolomia binotalis Zeller, and Ostrinia furnacalis Guenée (Shirai and Kawamoto, 1991; Shirai and Nakamura, 1995; Shirai, 1998). The adults of these three species do not require the intake of nectar for survival and reproduction. Miyahara (1990, 1997) suggests that the young adults of $C$. medinalis and $S$. recurvalis need to take in nectar for their survival and reproduction. Adult feeding after emergence may also have an influence on the long-flight behavior of $S$. recurvalis. To clarify this notion, the following experiments were conducted in the laboratory. First, the adult longevity, reproductive period, and fundamental flight activity (age-specific flight and suitable temperature range) were examined. Next, it was verified whether or not the active flight periods of $S$. recurvalis are separated from the reproductive periods. Third, the effect of deprivation of nectar (honey solution) on the flight activity of young adults was evaluated.

\section{MATERIALS AND METHODS}

Insects. Wild moths of $S$. recurvalis were collected from the pigweeds, Amaranthus viridis L. and $A$. retroflexus L. (Amaranthaceae), in Tsukuba, Japan, in early October 1996 and 1997. Ten pairs of wild males and females were placed in a mesh cage $(40 \times 40 \times 40 \mathrm{~cm})$ with spinach leaves, Spinacia oleracea L. (Chenopodiaceae), and a 5\% honey solution. Hatched larvae from eggs laid on the spinach leaves were reared on fully germinated spinach seeds and spinach leaves in a plastic dish (15 cm diameter, $9 \mathrm{~cm}$ depth). Before pupation, the fourth (last)-instar larvae were transferred into another plastic dish holding pieces of corrugated cardboard (i.e., used as the pupation site). Rearing was conducted under constant conditions of $25^{\circ} \mathrm{C}$ and $16 \mathrm{~L}: 8 \mathrm{D}$. The adults were sexed within $12 \mathrm{~h}$ of emergence. In the present study, adults of the second to fourth generations were used. The experiments on adult longevity and reproductive periods were conducted using the progeny from wild moths collected in 1996, while other flight activity experiments were conducted using the progeny of wild moths collected in 1997. Five pairs of adults were deposited as voucher specimens at the Laboratory of Insect Systematics, National Institute for AgroEnvironmental Sciences.

Survival and reproductive periods of mated adults. To evaluate the survival of mated adults, after emergence, 30 pairs of males and females were placed in a mesh cage $(40 \times 40 \times 40 \mathrm{~cm})$ containing a $5 \%$ honey solution, and kept under constant conditions of $23^{\circ} \mathrm{C}$ and $16 \mathrm{~L}: 8 \mathrm{D}$. Apart from this cage, three other cages with 30 pairs of males and females per cage were prepared under the same conditions as noted above, in order to evaluate the proportion of females that laid fertilized eggs. Eight to 12 females per cage were randomly chosen from these three cages $1-16 \mathrm{~d}$ after emergence, and placed individually in a plastic dish (15 cm diameter, $9 \mathrm{~cm}$ depth) with a fresh spinach leaf at night (for about $12 \mathrm{~h}$ ). During the 18-22 d after emergence, all of the females that survived were collected from the three cages, and placed individually in a plastic dish with a fresh spinach leaf. After oviposition in the dish, females were returned to their former cage. Eggs laid on the spinach leaves were kept until eclosion.

Flight activity evaluation using a flight-mill. Flight activity was measured by the same computer-aided flight-mill device used for $O$. furnacalis (Shirai, 1998). Fifteen or 16 individuals were simultaneously tested by one flight-mill system. All of the flight measurements, except for the experiment on suitable temperature range, were made continuously over a $24 \mathrm{~h}$ period at $23^{\circ} \mathrm{C}, 60 \%$ rh, with an illuminance of 10 lx. Flight activity was represented in terms of three parameters: total flight duration, flight velocity and the proportion of individuals showing continuous flight for more than $3 \mathrm{~h}$. This continuous flight duration $(3 \mathrm{~h})$ was determined on the basis of the average value $(194 \mathrm{~min}=3.2 \mathrm{~h})$ for the $3 \mathrm{~d}$-old unmated males which showed the longest continuous flights in the present study.

Suitable temperature range for flight. The flight activity of $4 \mathrm{~d}$-old unmated females was evaluated over a $24 \mathrm{~h}$ period, at $60 \%$ rh at eight different temperatures $(12,14,17,20,23,26,29$, and $32^{\circ} \mathrm{C}$ ) with an illuminance of $10 \mathrm{~lx}$. Twenty-seven to 33 individuals were tested at each temperature. 
From emergence to the days tested (at $4 \mathrm{~d}$-old), adults were placed in a mesh cage $(40 \times 40 \times 40 \mathrm{~cm})$ with a $5 \%$ honey solution and kept under constant conditions of $23^{\circ} \mathrm{C}, 16 \mathrm{~L}: 8 \mathrm{D}$.

Age-specific flight activity of unmated adults. From emergence to the days tested, unmated males and females were placed separately in the same type of cages and conditions as noted above. Flight activity was measured at $1-6,8,12$ and $16 \mathrm{~d}$-old; thirty specimens were tested at 1-12 d-old, and 20 specimens were tested at $16 \mathrm{~d}$-old. The individuals tested were not reused for flight measurements at any other age.

Flight activity of mated females. After emergence, 30 pairs of males and females were placed for 5 or $12 \mathrm{~d}$ in the same-scale cage and conditions as noted above. Without fresh spinach leaves, S. recurvalis females did not lay eggs in the cage. The flight activity of mated females was measured at $5 \mathrm{~d}$-old (early oviposition stage) and at $12 \mathrm{~d}$-old (middle stage) using a flight-mill. Thirty-four and 30 females were tested at 5 and $12 \mathrm{~d}$-old, respectively. All of the females were assumed as mated adult, because 90 to $100 \%$ of the females that were randomly chosen from the mesh cage had laid fertilized eggs between 4 and 12 d-old (see Fig. 1).

Effect of adult feeding on survival. After emergence, 30 unmated adults were placed in a mesh cage $(40 \times 40 \times 40 \mathrm{~cm})$ at $23^{\circ} \mathrm{C}, 16 \mathrm{~L}: 8 \mathrm{D}$, under five different food supply conditions: (1) 5\% honey solution was always provided, (2) water only, (3) no water, (4) water was provided between 1 and $5 \mathrm{~d}$ old, and then $5 \%$ honey solution was given from $6 \mathrm{~d}$-old, (5) no water was provided between 1 and $3 \mathrm{~d}$-old, and then 5\% honey solution was provided from 4 d-old. For Condition (4), water only was provided for $5 \mathrm{~d}$ period, because all of the males and females under Condition (2) survived until $5 \mathrm{~d}$ old. Similarly, for Condition (5), the moths were deprived of water for $3 \mathrm{~d}$, because all of the males and females survived until $3 \mathrm{~d}$-old under Condition (3).

Effect of deprivation of honey-solution on the subsequent flight. From emergence to the day of flight measurements, unmated adults were placed in a mesh cage with water only $\left(23^{\circ} \mathrm{C}, 16 \mathrm{~L}: 8 \mathrm{D}\right)$. Flight activity was measured at $2-5 \mathrm{~d}$-old, and the individuals tested were not reused for flight measurement at any other age. Twenty-five females and 20 males were tested at each age. The values for the adults supplied with honey solution were used from the data of age-specific flight activity.

Data analysis. The percentage data (proportion of non-fliers, survivorship and proportion of continuous flight) were tested using a chi-square test (Zar, 1998). Adult longevity, flight duration and flight velocity were analyzed by non-parametric comparison methods, Mann-Whitney $U$-test or Kruskal-Wallis test and Dunn multiple comparison (Sokal and Rohlf, 1981). The age-specific flight data in Fig. 2 were represented as a trend without statistical analysis.

\section{RESULTS}

\section{Survival and reproductive periods of mated adults}

The survivorship curve for $S$. recurvalis showed an identical pattern between the sexes, and the mean longevity did not differ significantly between females $(11.1 \mathrm{~d})$ and males $(10.1 \mathrm{~d})$ ( $U$-test, $5 \%$ level) (Fig. 1). The proportion of females that laid fertilized eggs increased from 2-3 d after emergence, reaching $100 \%$ at $4 \mathrm{~d}$-old, and remained at a high value of $90-100 \%$ until $16 \mathrm{~d}$-old. Approximately $60 \%$ of the females laid fertilized eggs during 18-22 d-old. Both sexes lived significantly shorter in the mated group ( $U$-test, $5 \%$ level) in comparison with the unmated adults supplied with a $5 \%$ honey solution (Table 1 ).

\section{Suitable temperature range for flight}

Between 14 and $23^{\circ} \mathrm{C}$, females flew longest and their total flight duration was nearly equal within the temperature range (Table 2). Over $26^{\circ} \mathrm{C}$, flight duration and proportion of continuous flight decreased as the temperature increased. The range of $17-23^{\circ} \mathrm{C}$ was likely optimal for long duration flights from the results of total flight duration and proportion of continuous flight. At 12 and $14^{\circ} \mathrm{C}, 15$ and $6 \%$ of the individuals tested were non-fliers that did not show any flight behavior during the flight-mill examination, but 11 and $27 \%$ of the adults were capable of continuous flight over $3 \mathrm{~h}$. The survival rate at the termination of the flightmill test decreased as temperatures increased between 12 and $32^{\circ} \mathrm{C}$.

\section{Age-specific flight activity of unmated adults}

The total flight duration of females was almost equal from 1 to $4 \mathrm{~d}$-old with no clear peak, slightly 


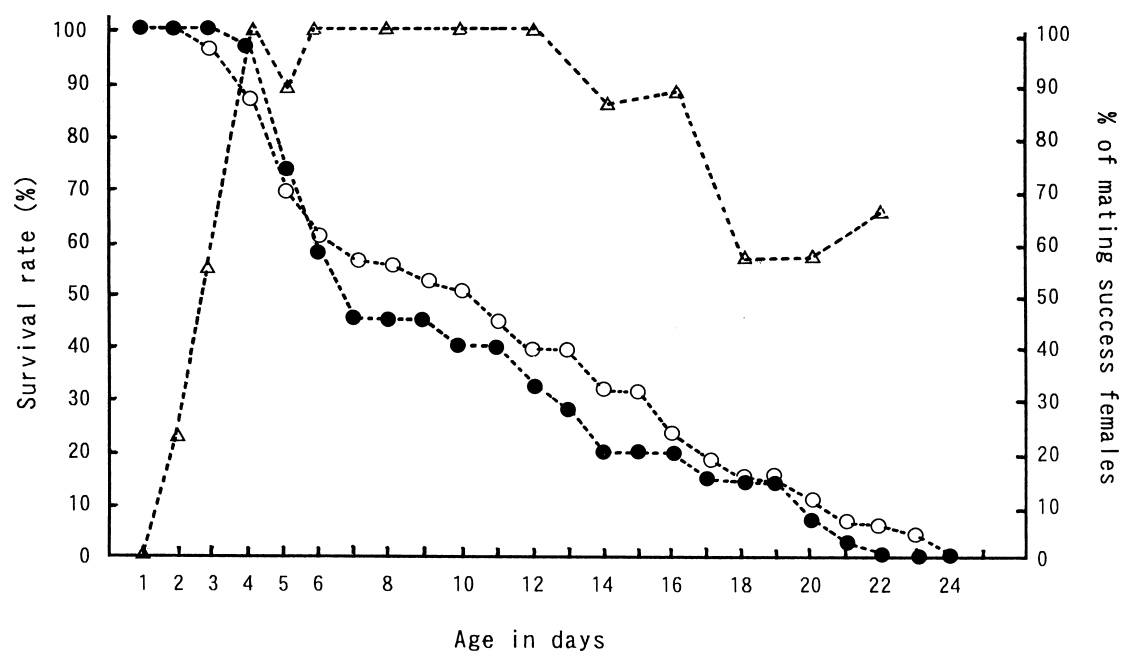

Fig. 1. Survivorship curves of mated females $(\bigcirc)$ and mated males $(\bullet)$ of Spoladea recurvalis, and proportion of females that laid fertilized eggs $(\triangle)$. For survivorship, 30 pairs of females and males were placed in a cage with a $5 \%$ honey solution. The proportion of females that laid fertilized eggs was evaluated using three other cages with 30 pairs of females and males per cage.

Table 1. Effect of food supply on adult longevity of unmated moths of Spoladea recurvalis

\begin{tabular}{|c|c|c|c|}
\hline \multirow{2}{*}{ Food supply } & \multicolumn{2}{|c|}{ Longevity (days) ${ }^{\mathrm{a}}$} & \multirow{2}{*}{$\begin{array}{c}U \text {-test }^{\mathrm{b}} \\
\text { (Female vs. Male) }\end{array}$} \\
\hline & Female & Male & \\
\hline $5 \%$ honey solution & $18.8 \pm 7.6 \mathrm{a}$ & $15.1 \pm 6.9 \mathrm{a}$ & $*$ \\
\hline Water only & $9.5 \pm 2.7 \mathrm{~b}$ & $7.5 \pm 1.6 \mathrm{~b}$ & ns \\
\hline No water & $5.7 \pm 1.0 \mathrm{c}$ & $4.5 \pm 0.8 \mathrm{c}$ & $\mathrm{ns}$ \\
\hline $\begin{array}{l}\text { Water only ( } 5 \text { days) } \\
\rightarrow 5 \% \text { honey solution }\end{array}$ & $21.6 \pm 8.4 \mathrm{a}$ & $14.1 \pm 7.5 \mathrm{a}$ & $*$ \\
\hline $\begin{array}{l}\text { No water ( } 3 \text { days) } \\
\rightarrow 5 \% \text { honey solution }\end{array}$ & $10.0 \pm 5.0 \mathrm{~b}$ & $7.5 \pm 4.1 \mathrm{~b}$ & $*$ \\
\hline
\end{tabular}

${ }^{\text {a }}$ Mean \pm SD $(n=30)$. Different letters for the same sex are significantly different at the $5 \%$ level by Kruskal-Wallis test and Dunn multiple comparison.

${ }^{\mathrm{b}}$ Asterisk shows a significant difference at the $5 \%$ level.

Table 2. Effects of temperature on flight behavior and survival of Spoladea recurvalis female moths under different temperature conditions $^{\mathrm{a}}$

\begin{tabular}{cccccccc}
\hline $\begin{array}{c}\text { Temperature } \\
\left({ }^{\circ} \mathrm{C}\right)\end{array}$ & $\begin{array}{c}\text { No. } \\
\text { tested }\end{array}$ & $\begin{array}{c}\text { \% of } \\
\text { non-fliers }\end{array}$ & $\begin{array}{c}\text { No. } \\
\text { fliers }\end{array}$ & $\begin{array}{c}\text { Flight duration } \\
\text { (min, Mean } \pm \text { SD) }\end{array}$ & $\begin{array}{c}\text { Flight velocity } \\
(\mathrm{m} / \text { min, Mean } \pm \text { SD) })\end{array}$ & $\begin{array}{c}\text { \% of moths showing } \\
\text { continuous flights } \\
\text { over } 180 \text { min }\end{array}$ & $\begin{array}{c}\text { \% survival at the } \\
\text { termination of } \\
\text { flight test }\end{array}$ \\
\hline 12 & 33 & $15.2 \mathrm{a}$ & 28 & $255 \pm 202 \mathrm{bc}$ & $19.9 \pm 7.8 \mathrm{c}$ & $10.7 \mathrm{c}$ & $96.4 \mathrm{a}$ \\
14 & 32 & $6.3 \mathrm{a}$ & 30 & $500 \pm 442 \mathrm{bc}$ & $27.7 \pm 9.2 \mathrm{~b}$ & $26.7 \mathrm{abc}$ & $93.3 \mathrm{a}$ \\
17 & 32 & $6.3 \mathrm{a}$ & 30 & $554 \pm 437 \mathrm{ab}$ & $30.6 \pm 7.5 \mathrm{~b}$ & $46.7 \mathrm{ab}$ & $93.3 \mathrm{a}$ \\
20 & 30 & $0.0 \mathrm{a}$ & 30 & $513 \pm 373 \mathrm{ab}$ & $32.0 \pm 7.9 \mathrm{ab}$ & $53.3 \mathrm{a}$ & $86.7 \mathrm{ab}$ \\
23 & 30 & $0.0 \mathrm{a}$ & 30 & $499 \pm 370 \mathrm{ab}$ & $37.3 \pm 9.2 \mathrm{a}$ & $43.3 \mathrm{ab}$ & $70.0 \mathrm{~b}$ \\
26 & 29 & $0.0 \mathrm{a}$ & 29 & $308 \pm 274 \mathrm{bc}$ & $26.7 \pm 11.0 \mathrm{bc}$ & $24.1 \mathrm{bc}$ & $62.1 \mathrm{bc}$ \\
29 & 30 & $0.0 \mathrm{a}$ & 30 & $222 \pm 154 \mathrm{c}$ & $30.1 \pm 11.0 \mathrm{ab}$ & $16.7 \mathrm{c}$ & $43.3 \mathrm{bc}$ \\
32 & 27 & $0.0 \mathrm{a}$ & 27 & $191 \pm 111 \mathrm{c}$ & $28.0 \pm 9.1 \mathrm{~b}$ & $14.8 \mathrm{c}$ & $33.3 \mathrm{c}$
\end{tabular}

${ }^{\text {a }}$ Unmated 4-d-females were tested. Different letters in the same column are significantly different at the 5\% level by KruskalWallis test and Dunn multiple comparison for flight duration and velocity, and by chi-square test for other parameters. 

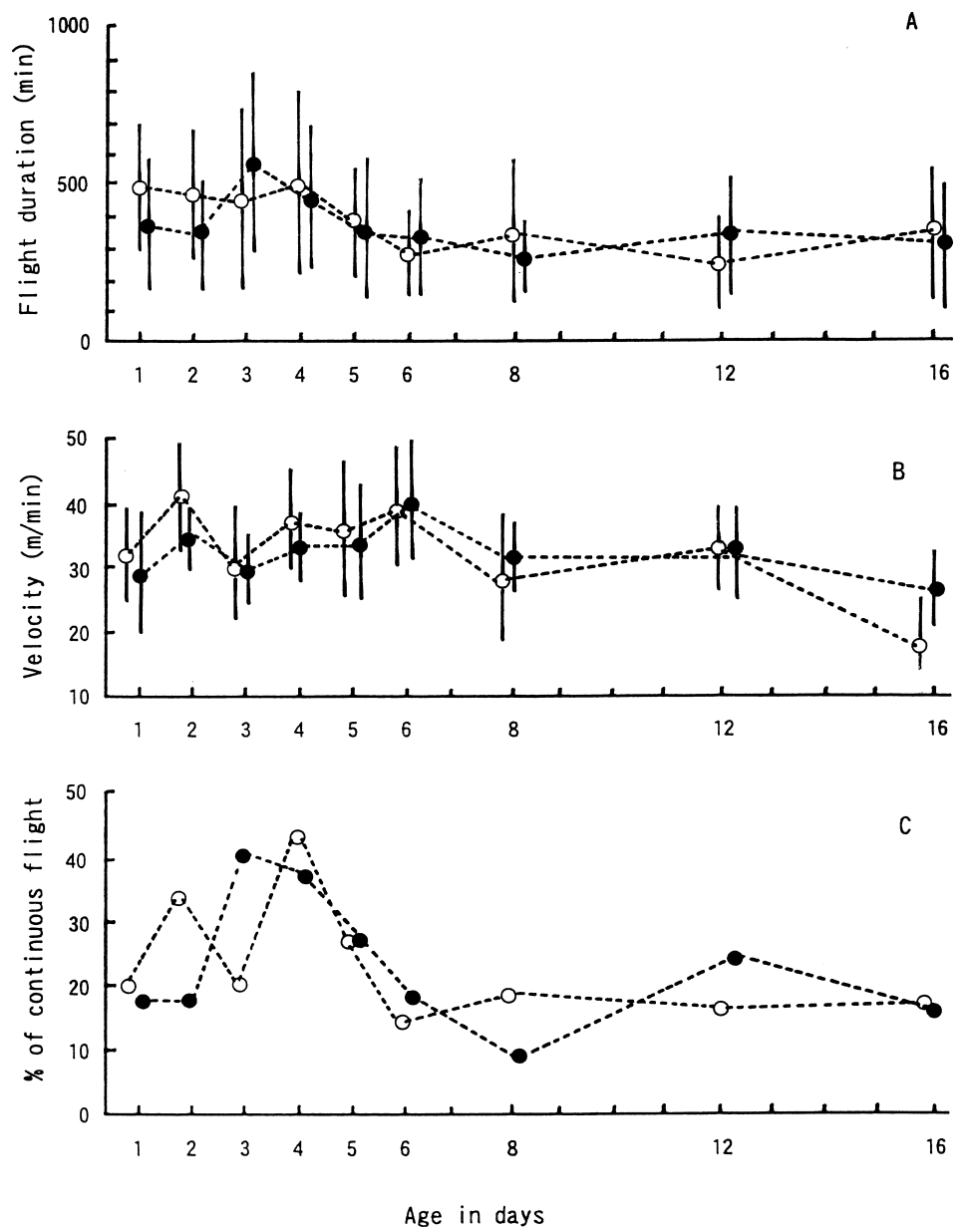

Fig. 2. Age-specific flight activity of unmated females $(\bigcirc)$ and males $(\bullet)$ of Spoladea recurvalis. Vertical bars indicate \pm SD. A, flight duration; B, flight velocity; C, proportion of individuals showing continuous flight for more than 180 min. $n=30$ for $1-12 \mathrm{~d}$-old moths, $n=20$ for $16 \mathrm{~d}$-old moths. No comparisons showed significant differences between sexes of the same ages at the $5 \%$ level using the Mann-Whitney $U$-test.

decreased at $5 \mathrm{~d}$-old, and then remained at this value until $16 \mathrm{~d}$-old (Fig. 2). Males showed a peak in flight duration at $3 \mathrm{~d}$-old, and flew constantly from 5 to $16 \mathrm{~d}$-old. The flight velocity of both sexes showed a constant value $(30-40 \mathrm{~m} / \mathrm{min})$ throughout the ages, except for females at $16 \mathrm{~d}$-old. The proportion of continuous flight peaked at 3-4 d-old, and decreased on and after $5 \mathrm{~d}$-old in both sexes. The total flight duration and proportion of continuous flight indicated that males and females fly most actively in the young adult stage until $4 \mathrm{~d}$-old. None of flight parameters (total flight duration, flight velocity, and continuous flight) showed clear differences in age-specific patterns between the sexes. In addition, no comparisons showed significant differences between sexes at the same age ( $U$ test, $5 \%$ level).

\section{Effect of mating status on flight activity}

At $5 \mathrm{~d}$-old, none of the flight parameters showed a significant difference between mated and unmated females (Fig. 3). At $12 \mathrm{~d}$-old (the middle of oviposition period), the total flight duration and proportion of continuous flight did not differ between mating status, although the flight velocity of mated females was significantly reduced.

\section{Effect of adult feeding on survival}

In both sexes, the two food supply conditions ("always honey solution" and "water only for $5 \mathrm{~d} \rightarrow$ honey solution") showed a significantly higher rate of survival than the other three food conditions, which strongly suggests that the uptake of honey solution is essential for adult survival (Table 1). When honey solution was first given at $6 \mathrm{~d}$-old 


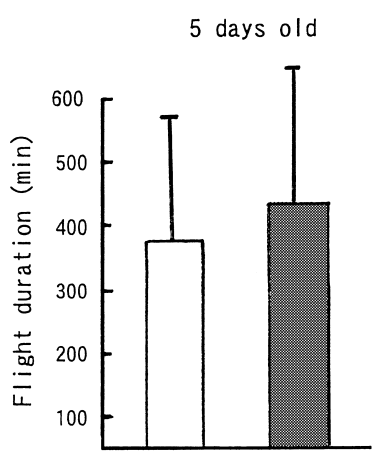

12 days old
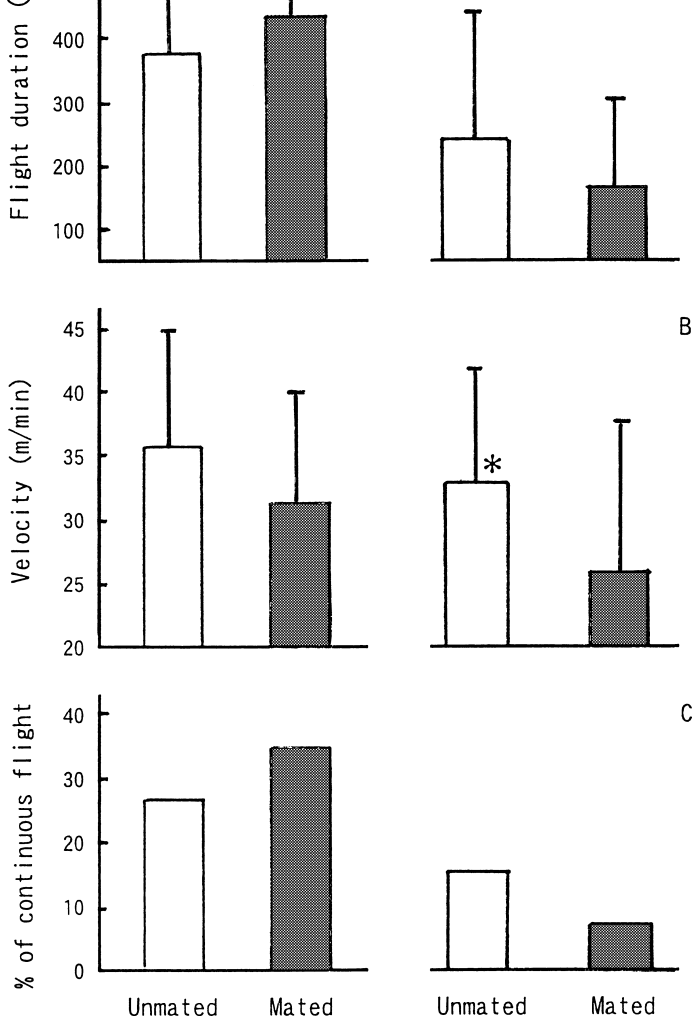

Fig. 3. Comparison of flight activity between unmated ( $\square$ ) and mated (ם) females of Spoladea recurvalis. Vertical bars indicate \pm SD. Left, 5 d-old females; right, 12 d-old females. A, flight duration; B, flight velocity; $\mathrm{C}$, proportion of individuals showing continuous flight for more than $180 \mathrm{~min}$.* shows a significant difference at the 5\% level using the Mann-Whitney $U$-test. $n=30$ for all groups.

after a $5 \mathrm{~d}$ starvation period, the overall longevity in both sexes did not differ from that of the moths continuously provided honey solution since emergence. When the adults were not provided water for $3 \mathrm{~d}$, however, their longevity declined sharply, even though honey solution was provided every day from $4 \mathrm{~d}$-old. Females survived significantly longer than males in the three treatments where honey solution was supplied, and females also tended to survive longer than males under the other two conditions (water only and no water) (Table 1).

Effect of deprivation of honey solution on the subsequent flight and survival

Females supplied with honey solution after
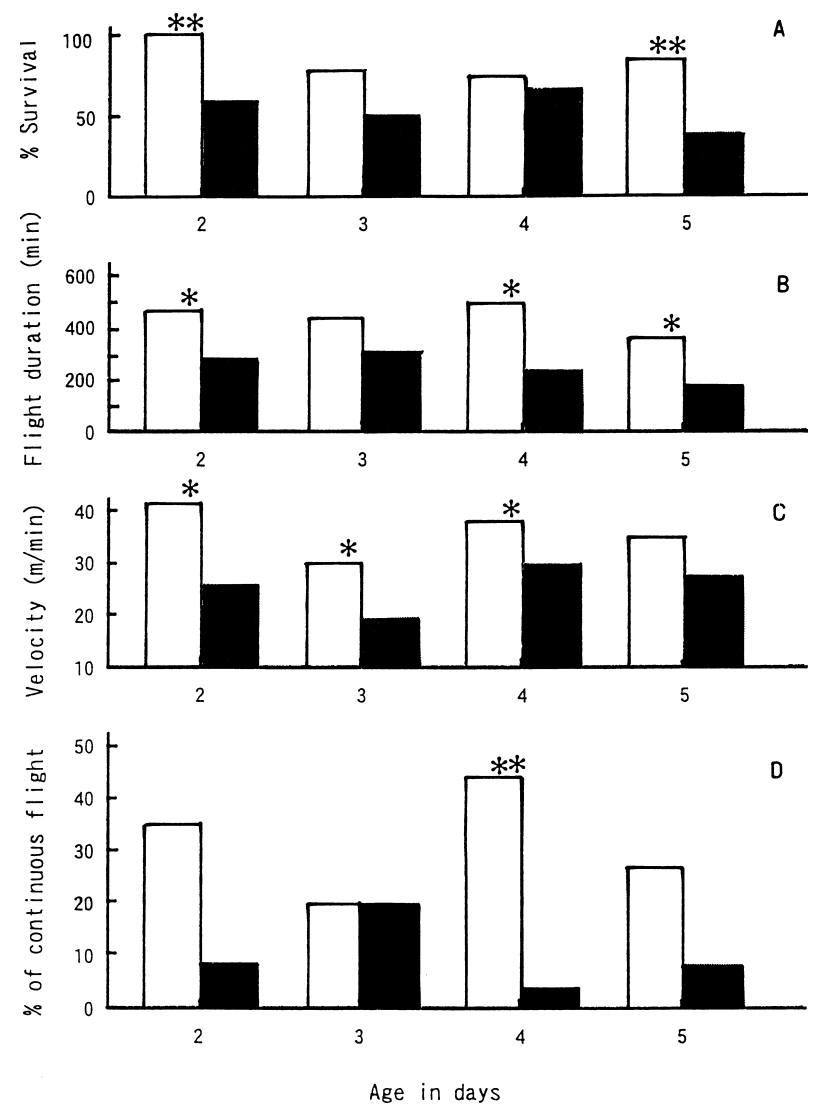

Fig. 4. Survival and flight activity of unmated females of Spoladea recurvalis deprived of honey solution after emergence. Left, $5 \%$ honey solution ( $\square$ ); right, water only (ם). A, survivorship at the termination of flight test; $\mathrm{B}$, flight duration; $\mathrm{C}$, flight velocity; D, proportion of individuals showing continuous flight for more than $180 \mathrm{~min}$. $^{*}$ and $* *$ show a significant difference at the $5 \%$ and $1 \%$ level using the Mann-Whitney $U$ test (flight duration and velocity) or chi-square test (survivorship and proportion of continuous flight). $n=25$ for water only group, $n=30$ for the honey solution-provided group.

emergence showed consistently higher values of survival rate at the termination of flight test, total flight duration, and flight velocity in comparison with those of females provided with water only, through the ages of 2-5d-old (Fig. 4). Females supplied with honey solution also showed a higher proportion of continuous flight than females given water only, except at $3 \mathrm{~d}$-old. Males supplied with honey solution also had a higher value for survival rate at termination, total flight duration, flight velocity, and proportion of continuous flight in comparison with males given water only (Fig. 5). Thus, deprivation of honey solution had a considerably adverse effect on subsequent flight activity and survival in both sexes. 

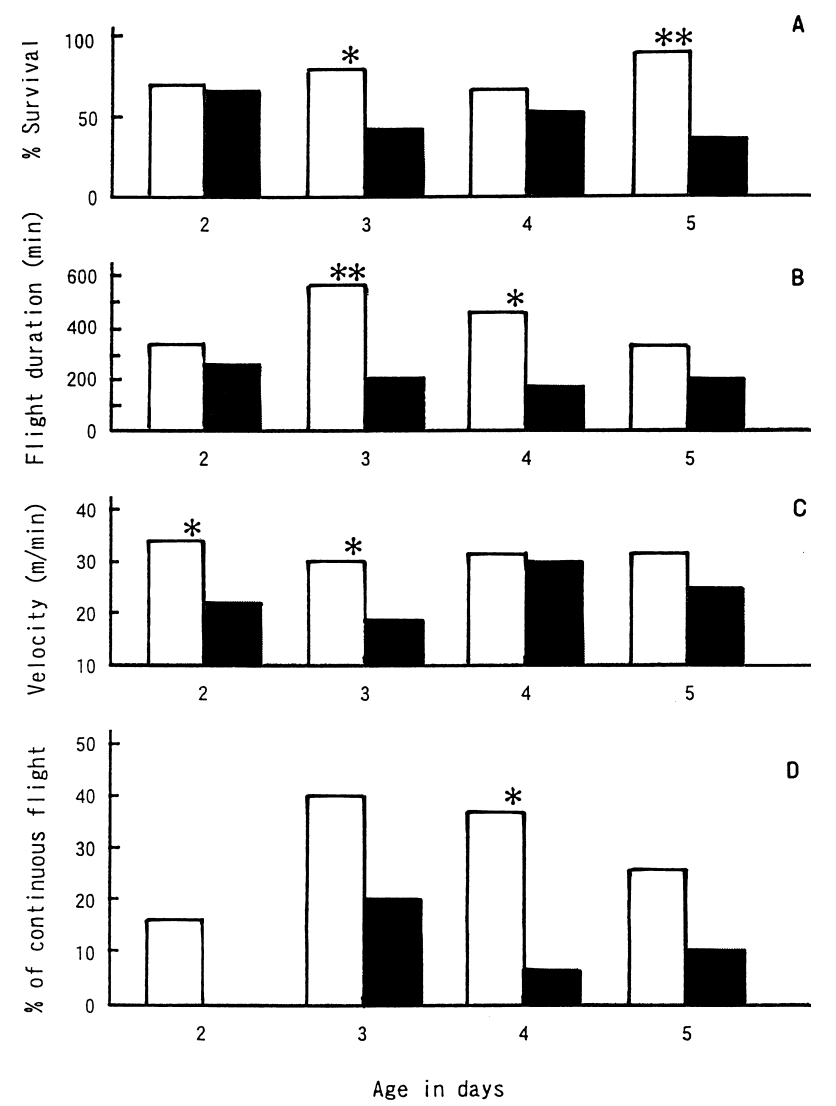

Fig. 5. Survival and flight activity of unmated males of Spoladea recurvalis deprived of honey solution. Left, 5\% honey solution $(\square)$; right, water only ( $\mathbf{\square})$. A, survivorship at the termination of flight test; $\mathrm{B}$, flight duration; $\mathrm{C}$, flight velocity; D, proportion of individuals showing continuous flight for more than $180 \mathrm{~min}^{*}$ and $* *$ show a significant difference at the $5 \%$ and $1 \%$ level using the Mann-Whitney $U$-test (flight duration and velocity) or chi-square test (survivorship and proportion of continuous flight). $n=25$ for water only group, $n=30$ for the honey solution-provided group.

\section{DISCUSSION}

\section{Fundamental flight activity of $S$. recurvalis}

$S$. recurvalis has a considerably longer life span, and continues to lay eggs over $20 \mathrm{~d}$ period after emergence (Fig. 1) in comparison with three Pyraustine moths (Table 3). Both sexes maintained a relatively high flight activity until $16 \mathrm{~d}$-old (Fig. 2). Such long-term maintenance of flight activity did not occur in the three species listed in Table 3. $S$. recurvalis does not only live longer, it is a tougher flier. In addition, this species showed a wider suitable temperature range for flight than the other Pyraustinae species; H. undalis and O. furnacalis flew most actively at approximately $23^{\circ} \mathrm{C}$ (Shirai and Kawamoto, 1991; Shirai, 1998), whereas $S$. recurvalis showed a high flight capability between $17^{\circ} \mathrm{C}$ and $23^{\circ} \mathrm{C}$. It is notable that $10 \%$ of the adults were capable of long-duration flight even at $12^{\circ} \mathrm{C}$ (Table 2), although their larval development was extremely inhibited below $18^{\circ} \mathrm{C}$ (Yamada et al., 1979). $S$ recurvalis is likely able to fly continuously for a long duration under low-temperature conditions, as the take-off flight makes the body temperature of the insect gradually increase (Dudley, 2000). The long-term reproductive period of females and this wide temperature range for flight are important characteristics since $S$. recurvalis is a serious pest of spinach and sugar beets (CAB International, 2000).

\section{Relationship between flight and reproduction}

Females had pre-oviposition periods of $2-3 \mathrm{~d}$ (Fig. 1), and flew actively at 2-4 d-old (Fig. 2); females of $S$. recurvalis did not show a clear tempo-

Table 3. Female flight and reproduction periods of four Pyraustine moths ${ }^{\mathrm{a}}$

\begin{tabular}{|c|c|c|c|c|c|c|}
\hline Species & $\begin{array}{l}\text { Requirement } \\
\text { for adult } \\
\text { nutrition }\end{array}$ & $\begin{array}{l}\text { Longevity of } \\
\text { unmated } \\
\text { moths (days) }\end{array}$ & $\begin{array}{l}\text { Pre-oviposition } \\
\text { period } \\
\text { (days) }\end{array}$ & $\begin{array}{l}\text { Age of peak } \\
\text { flight activity } \\
\text { (days) }\end{array}$ & $\begin{array}{c}\text { Effect of } \\
\text { mating status } \\
\text { on flight activity }\end{array}$ & Literature \\
\hline Crocidolomia binotalis & No & 10 & $2-3$ & 4 & unmated $>$ mated & $\begin{array}{l}\text { Shirai and } \\
\text { Nakamura } \\
\text { (1995) }\end{array}$ \\
\hline Hellula undalis & No & 10 & 0 & 1 & unmated $=$ mated & $\begin{array}{l}\text { Shirai and } \\
\text { Kawamoto } \\
\text { (1991) }\end{array}$ \\
\hline Ostrinia furnacalis & No & 10 & $3-4$ & 1 & unmated $=$ mated & Shirai (1998) \\
\hline Spoladea recurvalis & Yes & 19 & $2-3$ & 4 & unmated $=$ mated & present report \\
\hline
\end{tabular}

\footnotetext{
${ }^{\mathrm{a}}$ All experiments were carried out under constant conditions of $23^{\circ} \mathrm{C}$ and $16 \mathrm{~L}: 8 \mathrm{D}$.
} 
ral separation between their reproductive and active flight periods. In addition, the mating status of females did not affect their flight performance, except for flight velocity at $12 \mathrm{~d}$-old (Fig. 3). Thus, "oogenesis-flight syndrome" (Johnson, 1969) was not supported in the case of $S$. recurvalis. Gatehouse and Zhang (1995) stated that among the previously studied migratory lepidopterous insects, all species do not show a clear temporal discrimination or negative correlation between reproductive and flight traits. It may be favorable for the reproductive success of $S$. recurvalis that older-aged adults or mated females can maintain the capability of dispersing to more suitable habitats if necessary, because this species lives longer and can lay eggs for $20 \mathrm{~d}$.

Females of $S$. recurvalis caught on seashore vegetation in Japan shortly after immigration showed a lower proportion of mating success with immature ovaries, whereas females found in the inland vegetation fields during the same season were almost mated (Miyahara, 1990, 1997; Miyahara and Sogawa, 1996). This species disperses actively in the inland areas of Japan, with strong directional flight (Gyotoku et al., 1987). Although mating status was not determined from the present study, adults that fed fully on flower nectar after arriving from overseas are likely to take flight again, heading for inland areas.

\section{Adult feeding and long distance flights}

In contrast to Diptera or Orthoptera, a larger number of lepidopterous insects take food nourishment for egg production and propagation in the larval stage rather than in the adult stage. Species that have fully matured ovaries before eclosion are shorter-lived, and have only rudimentary mouthparts (Wheeler, 1996). However, the extent of requirements for adult feeding in noctuid and pyralid moths is likely to vary within a species. It depends on the experimental conditions related to adult longevity, mating status, and sexual maturity at eclosion (e.g., Colvin and Gatehouse (1993) and Coombs (1997) for Helicoverpa armigera Hübner; Leahy and Andow (1994) and Fadamiro and Baker (1999) for Ostrinia nubilalis Hübner).

The author conceived the following scenario from the present results (Table 1): young-aged adults can withstand several days of starvation and fly actively without feeding on nectar, and these young adults begin reproductive behavior after active flight and feeding on nectar. Thus, a strong propensity for long flights by $S$. recurvalis may be derived from dispersal flight to seek flower nectar. However, this prediction was not supported in either females or males (Figs. 4 and 5). Long flight performance and survivorship were largely reduced when honey solution was not provided even for one day after emergence. If there is appropriate vegetation with flower nectar in and near the point of birthplace, it is a disadvantage for newly emerged adults of $S$. recurvalis to take a long flight before feeding on the nectar. The necessity of feeding on nectar by adults is a genetically determined internal factor (Ims and Hjermann, 2001). Emerged adults of $S$. recurvalis that fly away from their birthplace to obtain flower nectar may be carried a longer distance than needed by the wind.

The effect of adult feeding on flight performance using a flight-measurement devise has not been well evaluated for lepidopterous insects including noctuid moths (Coombs, 1997). The present study did not evaluate either actual egg production related to adult feeding conditions or the flight activity of adults supplied with a honey solution after starvation period. Recent studies suggest that longdistance flight capability is dependent on multiple conditions, including both environmental and internal (genetic) ones (Ims and Hjermann, 2001). It is necessary to study the relationships among adult nutrition, long flights, and reproduction of S. recurvalis using a multifactorial approach.

\section{ACKNOWLEDGEMENTS}

The author would like to thank Drs. J. Badmin (Canterbury Christ Church University, UK), T. Wada (National Agricultural Research Center for Kyushu-Okinawa Region, Japan) and Y. Miyahara (Miyazaki City, Japan) for their valuable comments on this earlier draft and for useful information. Cordial thanks are also due to two anonymous reviewers for their valuable suggestions.

\section{REFERENCES}

Bottenberg, H., M. Tamo, D. Arodokoun, L. E. N. Jackai, B. B. Singh and O. Youm (1997) Population dynamics and migration of cowpea pests in northern Nigeria: implications for integrated pest management. In Advances in Cowpea Research (B. B. Singh, D. R. Mohan-Raj, K. E. Dashiell and L. E. N. Jackai eds.). Copublication of International Institute of Agriculture (IITA) and Japan International Research Center for Agricultural Sciences (JIRCAS), Ibadan, Nigeria, pp. 271-284. 
CAB International (1991) Distribution Maps of Pests. Series A, No. 527. Wallingford, UK. 1 p.

CAB International (2000) Crop Protection Compendium, Global Module. 2nd ed. (CD-ROM). Wallingford, UK.

Clancy, S. (1991) Psammotis pulveralis Hnb. (Lepidoptera: Pyralidae) and other migrant lepidoptera in the Dungeness Kent UK area 1990. Entomol. Rec. J. Variation 103: 51-52.

Colvin, J. and A. G. Gatehouse (1993) Migration and the effect of three environmental factors on the pre-reproductive period of the cotton-bollworm moth, Helicoverpa armigera. Physiol. Entomol. 18: 109-113.

Coombs, M. (1997) Tethered-flight and age-related reproductive performance of Helicoverpa punctigera (Wallengren) and $H$. armigera (Hübner) (Lepidoptera: Noctuidae). Aust. J. Zool. 45: 409-422.

Dingle, H. (1996) Migration, The Biology of Life on the Move. Oxford Univ. Press, New York. 474 pp.

Dudley, R. (2000) The Biomechanics of Insect Flight Form, Function, Evolution. Princeton Univ. Press, Princeton. $476 \mathrm{pp}$.

Fadamiro, H. Y. and T. C. Baker (1999) Reproductive performance and longevity of female European corn borer, Ostrinia nubilalis: effects of multiple mating, delay in mating, and adult feeding. J. Insect Physiol. 45: 385392.

Fujisaki, K. (1994) Evolution of dispersal polymorphisms in insects: a close examination of Roff's theory. Jpn. J. Appl. Entomol. Zool. 38: 231-244 (in Japanese).

Gatehouse, A. G. (1994) Insect migration: variability and success in a capricious environment. Res. Popul. Ecol. 36: $165-171$.

Gatehouse, A. G. and X. X. Zhang (1995) Migration potential in insects: variation in an uncertain environment. In Insect Migration (V. A. Drake and A. G. Gatehouse eds.). Cambridge Univ. Press, Cambridge, pp. 193-242.

Goater, B. (1986) British Pyralid Moths, A Guide to Their Identification. Harley Books, Essex. 175 pp.

Gyotoku, M., K. Ito and F. Nakasuji (1987) Monitoring of lepidopterous insect migrations using the migration trap. Jpn. J. Appl. Entomol. Zool. 31: 350-358 (in Japanese with English summary).

Ims, R. A. and D. Ø. Hjermann (2001) Condition-dependent dispersal. In Dispersal (J. Clobert, E. Danchin, A. A. Dhondt and J. D. Nichols eds.). Oxford Univ. Press, New York, pp. 203-216.

Johnson, C. G. (1969) Migration and Dispersal of Insects by Flight. Methuen, London. 763 pp.

Langellotto, G. A., R. F. Denno and J. R. Ott (2000) A tradeoff between flight capability and reproduction in males of a wing-dimorphic insect. Ecology 81: 865-875.

Leahy, T. C. and D. A. Andow (1994) Egg weight, fecundity, and longevity are increased by adult feeding in Ostrinia nubilalis (Lepidoptera: Pyralidae). Ann. Entomol. Soc. Am. 87: 342-349.

Miyahara, Y. (1990) The moths of the rice leaf roller, Cnaphalocrocis medinalis Guenée, and Hawaiian beet webworm, Hymenia recurvalis Fabricius, found on seashore vegetation during the summer and autumn.
Jpn. J. Appl. Entomol. Zool. 34: 21-27 (in Japanese with English summary).

Miyahara, Y. (1991) Examination of the overwintering of the Hawaiian beet webworm Hymenia recurvalis F. pupae. Proc. Assoc. Plant Prot. Kyushu 37: 156-159 (in Japanese).

Miyahara, Y. (1997) Immigration of Cnaphalocrosis medinalis Guenée and Spoladea recurvalis Fabricius around the rice field and seaside during the Bai-u season in 1996. Proc. Assoc. Plant Prot. Kyushu 43: 63-65 (in Japanese).

Miyahara, Y. and I. Sogawa (1996) Immigration of the Hawaiian beet webworm moth, Spoladea recurvalis, during the Bai-u season. Proc. Assoc. Plant Prot. Kyushu 42: 146-151 (in Japanese).

Rankin, M. A. and J. C. A. Burchsted (1992) The cost of migration in insects. Annu. Rev. Entomol. 37: 533-559.

Riley, J. R., D. R. Reynolds, A. D. Smith, A. S. Edwards, X. X. Zhang, X. N. Cheng, H. K. Wang, J. Y. Cheng and B. P. Zhai (1995) Observations of the autumn migration of the rice leaf roller Cnaphalocrosis medinalis (Lepidoptera: Pyralidae) and other moths in eastern China. Bull. Entomol. Res. 85: 397-414.

Riley, J. R., D. R. Reynolds, A. D. Smith, L. J. Rosenberg, X. N. Cheng, X. X. Zhang, G. M. Xu, J. J. Cheng, A. D. Bao, B. P. Zhai and H. K. Wang (1994) Observations of autumn migration of Nilaparvata lugens (Homoptera: Delphacidae) and other pests in east central China. Bull. Entomol. Res. 84: 389-402.

Saito, O. (2000) Flight activity changes of the cotton bollworm, Helicoverpa armigera (Hübner) (Lepidoptera: Noctuidae), by aging and copulation as measured by flight actograph. Appl. Entomol. Zool. 35: 53-61.

Shirai, Y. (1998) Laboratory evaluation of flight ability of the Oriental corn borer, Ostrinia furnacalis (Lepidoptera: Pyralidae). Bull. Entomol. Res. 88: 327-333.

Shirai, Y. and K. Kawamoto (1991) Laboratory evaluation of the flight ability of female adults of the cabbage webworm, Hellula undalis and reproductive success after flight. Bull. Natl. Res. Inst. Veg. Ornam. Plant Tea A 4: 31-40.

Shirai, Y. and S. Nakamura (1995) Laboratory evaluation of flight ability in the cabbage head caterpillar, Crocidolomia binotalis Zeller (Lepidoptera: Pyralidae). Jpn. J. Entomol. 63: 841-850.

Showers, W. B. (1997) Migratory ecology of the black cutworm. Annu. Rev. Entomol. 42: 393-425.

Sokal, R. R. and F. J. Rohlf (1981) Biometry: The Principles and Practice of Statistics in Biological Research. 2nd ed. Freeman, New York. 859 pp.

Suzuki, H., K. Hayashi and S. Asahina (1977) Notes on the transoceanic insects captured on East China Sea in 1976. Trop. Med. 19: 85-93.

Wada, T., Y. Ogawa and T. Nakasuga (1988) Geographical difference in mated status and autumn migration in the rice leaf roller moth, Cnaphalocrosis medinalis. Entomol. Exp. Appl. 46: 141-148.

Waldbauer, G. P., A. P. Marciano and P. K. Pathak (1980) Life-span and fecundity of adult rice leaf folder Cnaphalocrosis medinalis (Guenée) (Lepidoptera: Pyrali- 
dae), on sugar sources, including honeydew from the brown planthopper, Nilaparvata lugens (Stål) (Hemiptera: Delphacidae). Bull. Entomol. Res. 70: 65-71.

Wheeler, D. (1996) The role of nourishment in oogenesis. Annu. Rev. Entomol. 41: 407-431.

Yamada, H. and T. Koshihara (1976) Development of the Hawaiian beet webworm, Hymenia recurvalis (Fabricius) (Lepidoptera: Pyralidae). Jpn. J. Appl. Entomol. Zool. 20: 213-214 (in Japanese).

Yamada, H., T. Koshihara and K. Tanaka (1979) Biology and seasonal life history of the Hawaiian beet webworm, $\mathrm{Hy}$ menia recurvalis (Fabricius). Bull. Veg. Ornam. Crops
Res. Stn. A6: 171-184 (in Japanese with English summary).

Yoshimatsu, S. (1991) Lepidopterous insects captured on East China Sea from 1981 to 1987. Jpn. J. Entomol. 59: 811-820 (in Japanese with English summary).

Zar, J. H. (1998) Biostatistical Analysis. 4th ed. Prentice Hall, Upper Saddle River. 929 pp.

Zera, A. J. and R. F. Denno (1997) Dispersal polymorphisms in insects: integrating physiology, genetics and ecology. Annu. Rev. Entomol. 42: 207-231.

Zhang, B-C. (1994) Index of Economically Important Lepidoptera. CABI Publishing, Wallingford, UK. 599 pp. 